Marian J. Ptak

\title{
Kilka uwag o ustroju politycznym księstw oświęcimskiego i zatorskiego do 1563 roku
}

\section{Ein paar Bemerkungen über politische Verfassung der Fürstentümer Auschwitz und Zator, bis zum Jahr 1563}

1. Stan badań. 2. Terytorium księstwa oświęcimskiego i jego struktura. 3. Pozycja ustrojowo-prawna książąt oświęcimskich. 4. Zwierzchnictwo lenne królów polskich. 5. Rada książęca. 6. Starsi ziemscy. 7. Relacje między sądem ziemskim i sejmikiem.

1. Stand der Forschungen. 2. Das Territorium vom Fürstentum Auschwitz und seine Struktur. 3. Die Verfasungssechtliche Stellung der Fürsten von Auschwitz. 4. Die Lehnshoheit der polnischen Könige. 5. Fürstenrat. 6. Landesältesten. 7. Die Beziehungen zwischen dem Landrecht und Landtag.

1. Ustrój polityczny księstw oświęcimskiego i zatorskiego do czasu ich inkorporacji do Korony w 1563 r. nie został wnikliwie zbadany i opisany. Przyczynę tego stanu rzeczy należy upatrywać nie tylko w stosunkowo skąpym materiale źródłowym, którym aktualnie dysponujemy, ale również w niedostatecznym wykorzystaniu źródel istniejących oraz w słabej znajomości ustrojowych realiów Śląska ${ }^{1}$. Na ciągle znaczne w tym zakresie możliwości poznawcze $\mathrm{i}$ interpretacyjne wskazują poniższe uwagi.

2. Księstwo oświęcimskie wyodrębnione zostało z księstwa cieszyńskiego w 1314 lub 1315 r., na mocy dynastycznego prawa Piastów ${ }^{2}$. Obejmowało ono początkowo miasto i zamek Oświęcim - ośrodek księstwa, ponadto miasto Zator oraz miasteczka: Kęty, Żywiec, Wadowice i Spytkowice wraz

\footnotetext{
1 Odnosi się to również do książki A. Nowakowski ego, Dzieje ustroju i prawa księstw oświęcimskiego $i$ zatorskiego, Białystok 1988. Ponieważ zawiera ona wykaz podstawowych żódeł i opracowań dotyczących dziejów tych księstw, rezygnuję z ich szerszego przytaczania.

${ }^{2}$ K. J a siński, Genealogia Piastów ślqskich, t. III, Wrocław 1977, s. 34.
} 
$\mathrm{z}$ nieokreśloną liczbą $\mathrm{wsi}^{3}$. Zapewne do początku $\mathrm{XV}$ w. nie było ono podzielone na mniejsze jednostki terytorialne $\mathrm{z}$ ośrodkami miejskimi, zwane na Śląsku ziemiami, dystryktami, okręgami albo weichbildami. Sytuacja ta uległa zmianie w 1414 r., w którym książę cieszyński Bolesław - po ustaniu jego opieki nad nieletnim Kazimierzem oświęcimskim -- przekazał mu we władanie ziemię oświęcimską, toszecką oraz połowę Gliwic, zapewne $\mathrm{z}$ połową przynależnej do nich ziemi ${ }^{4}$. Nie istniała zatem $w$ tym czasie ziemia zatorska. Swoje powstanie zawdzięczała bowiem podziałowi księstwa oświęcimskiego, dokonanemu w 1445 r. między synów Kazimierza: Waclawa, Przemyslawa i Jana IV ${ }^{5}$. Ziemia zatorska - obejmująca stołeczny Zator wraz z Wadowicami oraz okolicznymi wsiami - jako odrębne księstwo została przyznana Wacławowi. W wyniku tego podziału powstało również księstwo toszeckie z miastem Toszkiem i Pyskowicami oraz okolicznymi wsiami, które przypadło Przemkowi ${ }^{6}$. Nie miało ono łączności terytorialnej $\mathrm{z}$ księstwem oświęcimskim i zatorskim. Janowi IV pozostała jako kontynuacja dawnego księstwa ziemia oświęcimska pomniejszona oczywiście o ziemię zatorską. Polowa miasta i ziemi gliwickiej znalazły się $\mathrm{w}$ obcych rękach, zapewne $\mathrm{w}$ formie zastawu. W dokumencie podziałowym z 1445 r. przewidywano odzyskanie tej ziemi jako "majątku dziedzicznego" książąt oświęcimskich, i następnie jej podzial między księciem oświęcimskim i toszeckim, z wykluczeniem księcia zatorskiego. Odtąd dzieje ustrojowe każdego $\mathrm{z}$ tych księstw toczyły się odrębnym torem. Księstwo toszeckie, po śmierci Przemka w 1493 r., stało się wolnym państwem stanowym (Freie Standesherrschaft), następnie w latach 1495-1496 znalazło się we władaniu Jana IV oświęcimskiego, aby ostatecznie wejść w skład księstwa opolsko-raciborskiego, jako jeden $\mathrm{z}$ wielu jego okręgów (weichbildów). Odmiennie potoczyły się losy księstwa oświęcimskiego i zatorskiego. Utracily one własnych książąt i w pierwszej połowie XVI w. zostały połączone, przy zachowaniu pewnych odrębności ustrojowo-prawnych, i już jako księstwo oświęcimsko-zatorskie inkorporowano je do Korony i województwa krakowskiego. Zajmowało ono powierzchnię $2473 \mathrm{~km}^{2}$, przy tym oświęcimskie 1800, a zatorskie $673 \mathrm{~km}$ kwadratowe ${ }^{7}$. Po podziale z $1445 \mathrm{r}$.

${ }^{3}$ Dokument lenny z 1327 r., Lehns = und Besitzurkunden Schlesiens und seiner einzelnen Fürstenthümer im Mittelalter, C. Grünhagen und H. Markgraf, Th. II, Leipzig 1883, s. 577 [dalej cyt.: GM II].

4 Ibidem, s. 562.

5 Ibidem, s. $588-592$.

- Toszek był starym grodem kasztelańskim, który po powstaniu na podgrodziu miasta stał się ośrodkiem weichbildu. Pyskowice stanowiły początkowo także centrum oddzielnego weichbildu i jeszcze w latach sześćdziesiątych XIV w. zachowały ten status. Zapewne już u schyłku tego stulecia został on wcielony do weichbildu toszeckiego. J. $\mathrm{Chrząszcz}$, Die Geschichte der Städte Peiskretscham und Tost sowie des Kreises Tost-Gleiwitz, Peiskretscham 1927.

7 J. S t a nek, Z dziejów Ziemi Oświęcimskiej, Kraków 1959, s. 253. 
księstwo oświęcimskie obejmowało dwa tzw. grody główne (Oświęcim i Wołek), dwa miasta (Oświęcim i Kęty) oraz 45 wsi $^{8}$. Odpowiadało zatem śląskiemu weichbildowi średniej wielkości.

3. Podmiotem najwyższej władzy politycznej w księstwie oświęcimskim był początkowo wyłącznie książę. Jego pozycję ustrojową w samym księstwie i poza nim określało prawo książęce (ius ducale). Treść tego prawa zmieniała się jednak wraz z ewolucją warunków, w których funkcjonowała władza książęca. Stanowisko udzielnego księcia miał pierwszy książę oświęcimski Wladysław oraz jego syn Jan I, ale tylko w okresie pierwszych pięciu lat swojego panowania. W 1327 r. uznał się on bowiem, w imieniu własnym oraz swoich sukcesorów, wasalem króla czeskiego Jana Luksemburskiego'. Odtąd pozycję księcia oświęcimskiego wobec króla czeskiego miało regulować prawo lenne (ius feodale) traktowane jednak bardzo powierzchownie. W dokumencie z 24 lutego $1327 \mathrm{r}$. Jan I zobowiązał się bowiem tylko do złożenia królowi czeskiemu hołdu wierności (homagium fidelitatis). Nawiązanie stosunku lennego nie oznaczało zatem automatycznego zastąpienia prawa książęcego prawem lennym. Dowodzi tego dokument króla czeskiego wystawiony Mikołajowi opawskiemu z dynastii Przemyślidów 14 stycznia 1337 r., stwierdzający, iż Jan oświęcimski oraz kilku innych książąt śląskich władają swoimi księstwami non iure feudali sed pocius Polonicali $^{10}$. Znacznie później tenże Jan wraz z trzema innymi książętami śląskimi w dokumencie wystawionym 3 października 1355 r. stwierdzil, iż król czeski sprawuje nad nimi władze zwierzchnią in Polonie rite ${ }^{11}$. Prowadzi to do ważnej konstatacji: pozycję ustrojową książąt oświęcimskich regulowało nadal polskie prawo książęce ${ }^{12}$. Z biegiem czasu bylo ono oczywiście modyfikowane przez prawo lenn chorągiewnych, królewskie akty prawne, a zwłaszcza przez zwyczaj i kształtujące się $\mathrm{z}$ wolna prawo zwyczajowe. Nie miejsce tutaj na całościowe jego przedstawienie i scharakteryzowanie. Wystarczy ograniczyć się do stwierdzenia, iż regulowało ono nie tylko stosunek księcia do króla czeskiego, ale również kwestie związane z sukcesją władzy książęcej, forum sądowym księcia oraz prawami i obowiązkami wobec ludności zamieszkalej na terytorium ksiestwa.

\footnotetext{
${ }^{8}$ Zob. dokument z 1457 r., GM II, s. 606 610. Najstarsza mapa księstwa oświęcimskiego i zatorskiego pochodzi z 1563 r. (Ducatus Oswieczensis et Zotoriensis descriptio in Venezia alla libraria del s. Marco). Jej dwa egzemplarze znajdowały się m. in. w Bibliotece Miejskiej we Wrocławiu.

${ }^{9} \mathrm{GM}$ II, s. 577.

${ }^{10}$ Ibidem, s. 383-385.

1 Ibidem, s. 422-423.

${ }^{12}$ K. Or zech how k i, Powstanie pojęcia „prawa ksiqżęcego" na Ślqsku, [w:] Studia z dziejów kultury i ideologit, Wrocław 1968, s. 90-98.
} 
4. Zwierzchnictwo królów czeskich nad książętami oświęcimskimi przetrwało do wieku XV, w którym ich miejsce zajęli królowie polscy. Określali oni stosunek zależności książąt oświęcimskich od siebie mianem protekcji albo opieki, ale stosowne dokumenty poshugiwały się też terminologią prawa lennego. $\mathrm{Na}$ uwagę zasługuje fakt, iż przejęcie zwierzchnictwa nad książętami oświęcimskimi nastąpiło po uprzedniej zgodzie króla czeskiego, który w dokumencie z $1440 \mathrm{r}$. uznal, iż nie może zapewnić swoim wasalom tj. Wacławowi, Przemkowi i Janowi IV, skutecznej rady i pomocy w sporze $\mathrm{z}$ królem polskim ${ }^{13}$. W dokumencie tym Władysław Pogrobowiec otwarcie więc przyznal, iż jako senior nie może wywiązać się ze swojego podstawowego obowiązku, tj. zapewnienia swoim wasalom spokojnego posiadania lenna, i w związku $z$ tym zezwala im dla ochrony ich dóbr, gdy zajdzie taka potrzeba, na poddanie się zwierzchnictwu „,polskiej Rzeszy” (Polnesche reych, Polnesche Konigreych). Z możliwości tej skorzystał książę Waclaw już po roku, w zamian za zwrot przez króla polskiego ziemi zatorskiej. W dokumencie z 8 stycznia 1441 r. przyrzekł on w najbliższym czasie zjawić się w Krakowie i złożyć wraz z milicia nobilitate et coincolis Oswancimiensibus omagium fidelitatis et servitutis domino regi et eius corone Polonie $^{14}$. Na uwage zasługują odmienności tego aktu w porównaniu $\mathrm{z}$ wcześniejszym, z 1327 r. Wacław zobowiązywal się do złożenia nie tylko hołdu wierności, ale również służebności. Hold miał być złożony nie tylko przez samego księcia, ale również przez inne podmioty politycznie czynne w księstwie, tj. przez szlachtę i ,wspólmieszkańców" księstwa; pod tym ostatnim terminem należy zapewne rozumieć innych ziemian i niektóre miasta. Ziemianie oświęcimscy stali się bowiem gwarantem dotrzymania przyrzeczenia książęcego, co znalazło wyraz w dokumencie tej samej daty ${ }^{15}$. Wreszcie odbiorcą hołdu był nie tylko król, ale również Korona Polska, czyli Rzeczpospolita. Pozycję Wacława zatorskiego wobec króla i Korony Polskiej określa dokument Kazimierza Jagiellończyka, wydany po $1447 \mathrm{r} \cdot{ }^{16}$ Potwierdzał on dotychczasowe stanowisko księcia $\mathrm{i}$ wymienił te prawa króla polskiego, które przysługiwały mu jako seniorowi. Mógł sie przeto domagać od księcia udziału w wyprawie wojennej i płacenia podatków, gdy obowiązki te zostaną nałożone na inne ziemie Królestwa Polskiego, oraz innych świadczeń (servitia et gravamina) od podleglych mu osób i ich ruchomych i nieruchomych majątków. Dokument potwierdzał poza tym zwierzchnictwo księcia, zwłaszcza pelne zwierzchnictwo sądowe, przez sformułowanie zakazu odwolywania się i apelowania mieszkańców księstwa do sądów polskich. Pozwala to na stwierdzenie, że pozycja ustrojowa księcia zatorskiego $w$ relacji do nowego seniora nie uległa formalnemu osłabieniu.

${ }^{13}$ GM II, s. 582-583. Autentyczność tego dokumentu budzi pewne wątpliwości.

${ }^{14}$ Ibidem, s. 584-586.

is Ibidem, s. 586-587.

16 Ibidem, s. 592-593. 
Jan IV oświęcimski popadł w zależność lenną od króla polskiego nieco później, ale szybko utracil swoje księstwo. W 1453 r. wyrazil gotowość zostania lennikiem króla i równocześnie sprzedania mu księstwa oświęcimskiego ${ }^{17}$. Oferta księcia została przyjęta przez monarchę i już w $1454 \mathrm{r}$. Jan IV został lennikiem, a w trzy lata później sprzedał królowi Polski całe księstwo $^{18}$. Zatem w 1457 r. księstwo oświęcimskie przestało być lennem, a jego dotychczasowy książę - lennikiem polskim. Uzyskane $z$ tej sprzedaży pieniądze Jan IV zapewne przeznaczyl na odzyskanie ziemi gliwickiej (połowy), ponieważ tytułuje się odtąd księciem gliwickim i w Gliwicach wystawia dokumenty ${ }^{19}$. Następnie w 1465 r. zakupil na Wiederkauf weichbild ujazdowski od biskupa wrocławskiego ${ }^{20}$. W $1482 \mathrm{r}$. sprzedal swoją część Gliwic z weichbildem, i odtąd aż do śmierci w 1496 r. tytułował się tylko księciem ujazdowskim ${ }^{21}$.

Swoje księstwo sprzedał królowi polskiemu i Koronie Polskiej także ostatni książę zatorski, Jan V, ale uczynił to dopiero w 1494 r. W przeciwieństwie do Jana IV, zachował $w$ nim jednak dożywotnią władzę, aż do swojej tragicznej śmierci w 1513 r. Data ta oznacza koniec ponad sześćdziesięcioletnich dziejów księstwa zatorskiego jako lenna polskiego, charakteryzujących się podziałem zwierzchniej władzy politycznej między króla polskiego i księcia. Powstała $w$ ten sposób formalna przesłanka do połączenia księstwa zatorskiego $\mathrm{z}$ oświęcimskim $\mathrm{w}$ postaci ich ustrojowo-prawnej unii, która wyraziła się później w dwuczłonowej nazwie nowego księstwa.

5. W życiu politycznym księstwa oświęcimskiego i księstw później z niego wyodrębnionych brały udział uprzywilejowane jednostki i grupy spoleczne. W początkowym okresie jawi się on bardzo mgliście, głównie za sprawą mało wymownych źródeł. Dopiero dokument Jana I z 17 marca 1346 r., uwalniający klasztor w Mogile i mieszkańców wsi Woźniki i Żygodowice od wszelkich danin i ciężarów w zamian za zniesienie ciążącej na księciu i księstwie ekskomuniki i interdyktu, rozjaśnia ten obraz. Stwierdza on bowiem, iż decyzja ta została podjęta za radą (consilium) stryja, Władysława bytomskiego ac aliorum nobilium baronum terrae nostrae sapientum ${ }^{22}$. Ponad sto lat później, w 1449 r., Wacław zatorski sprzedał klasztorowi w Mogile „Zwierzchnie prawo książęce" w dwóch wsiach matura nostra nostrorumque dominorum ad nostrum consilium tunc pertinentium deliberatione et consensu

\footnotetext{
${ }^{17}$ Ibidem, s. 594-597.

${ }^{18}$ Ibidem, s. 601-602, 606-610.

1921 II 1457 r., 11 V 1464 r. (ibidem, s. 606-610, 613).

${ }^{20}$ Ibidem, s. 376.

${ }^{21}$ Ibidem, s. 339.

${ }^{22}$ Diplomata monasterii Clarae Tumbae prope Cracoviam, Kraków 1865, nr LXIV.
} 
speciali. Książę wystawil w tej sprawie dokument, przy udziale nobilibus viris, dominis ac terrigenis nostris consiliariis fidelibus nostris dilecti ${ }^{23}$. Dokumenty te wskazują na możliwość zasięgania rady u różnie określanych podmiotów: innych Piastów śląskich, szlachty, baronów, mędrców, panów, ziemian, radców i wiernych księcia. Organizacyjne formy udzielania takiej rady mogły być różne.

Ważnym organem służącym księciu radą, a w pewnych okolicznościach także udzielającym zgody na podejmowane przez niego czynności, była rada książęca. Chodzi przy tym o radę w ścisłym tego słowa znaczeniu, tj. o organ książęcy składający się z radców (consiliari, Räthe), czyli wyspecjalizowanych i mianowanych przez księcia urzędników, którzy na Śląsku pojawili się już w drugiej połowie XIII w. O funkcjonowaniu takiej rady w omawianych księstwach świadczy dokument wystawiony 8 stycznia 1441 r. w Zatorze przez Waclawa oświęcimskiego, w którym nostrorum consiliariorum consensu przyrzekal złożyć hołd królowi polskiemu, w zamian za przekazany mu przez niego Zator wraz $\mathrm{z}$ przynależnościami ${ }^{24}$. W innym dokumencie, z 7 czerwca 1453 r., Jan oświęcimski zobowiązał się nostrorum consiliariorum sciencie deliberacione consilio et assensu zrezygnować $\mathrm{z}$ księstwa oświęcimskiego na rzecz króla i Korony Polskiej oraz złożyć stosowny hold ${ }^{25}$. W kolejnym dokumencie, z 21 lutego 1457 r., ten sam książę oznajmia o sprzedaży księstwa królowi polskiemu, po naradzie ze swoimi braćmi oraz baronami i radcami ${ }^{26}$. Przykłady te dowodzą wysokiej pozycji rady książęcej, skoro wyrażała ona swoją wolę $w$ sprawach najwyższej rangi: zmiany seniora, sprzedaży zwierzchnictwa terytorialnego nad księstwem i w rezultacie perspektywy włączenia do nowego organizmu państwowego.

6. Dokument z 4 lipca 1438 r., wystawiony przez Wacława oświęcimskiego i potwierdzający sprzedaż „na wyderkauf” czynszów i innych korzyści w pewnej wsi, stwierdza dokonanie tej czynności za radą radców i tzw. starszych manów ${ }^{27}$. W 1445 r. Przemyslaw toszecki sprzedał swoje zwierzchnie prawo na dwóch posiadłościach, w okręgu żywieckim mit Rate und wissen unser eldesten ${ }^{28}$. Owych starszych manów względnie starszych, wielu autorów utożsamia $z$ radcami, głosząc, iż są to różne nazwy tego samego urzędu ${ }^{29}$.

\footnotetext{
${ }^{23}$ Ibidem, nr CXXXIV.

${ }^{24}$ GM II, s. 584-586.

${ }^{25}$ Ibidem, s. 594-597.

${ }^{26}$ Ibidem, s. 606-610.

${ }^{27}$ Codex Diplomaticus Silesiae [dalej CDS] t. 6, nr 197.

${ }^{28}$ CDS t. 2, nr 57.

${ }^{29}$ Tak np. G. Croon, Die landständische Verfassung von Schweidnitz-Jauer. Zur Geschichte des Ständewesens in Schlesien, CDS 1. 27, Breslau 1912, s. 8 i n., oraz K. O r zech ow sk i, Ogólnoślqskie zgromadzenia stanowe, Wrocław 1979, s. 87.
} 
Tymczasem, jak dowodzą szczególowe studia nad ustrojem poszczególnych śląskich księstw, starsi byli - w przeciwienstwie do radców - urzędnikami korporacji ziemian $\mathrm{w}$ poszczególnych ziemiach. $\mathrm{Z}$ tego powodu określano ich później mianem starszych ziemskich (Landesälteste). Do podstawowych ich zadań należało kierowanie określoną terytorialną korporacją ziemian i reprezentowanie jej na zewnątrz. Innymi słowy, występowanie starszych ziemskich dowodzi funkcjonowania $w$ pełni wykształconych korporacji stanowych ziemian w księstwie oświęcimskim i następnie zatorskim oraz toszeckim, które za ich pośrednictwem partycypowały w życiu politycznym. Starsi, których było przeważnie kilku, tworzyli urzędnicze kolegium stanowe i równocześnie formę reprezentacyjnego zgromadzenia stanowego, które funkcjonowało $w$ okresie między sesjami sejmików księstw. Przytoczone przykłady wskazują, iż książę mógł zasięgnąc $w$ danej sprawie rady swoich radców i starszych albo tylko starszych. Starsi ziemscy zanikają jednak w źródłach drugiej połowy XV w. Stało się tak zapewne w wyniku łączenia funkcji starszego ziemskiego z funkcją sędziego i ławnika sądu ziemskiego.

7. Sąd ziemski znajdował się $w$ tym czasie $w$ każdym $z$ trzech wyodrębnionych w 1414 r. księstw. Bliższe informacje o skladzie takiego sądu posiadamy jednak tylko $w$ odniesieniu do księstwa oświęcimskiego i zatorskiego ${ }^{30}$. Wynika $z$ nich, iż w latach 1440-1505 zasiadało w nim (oprócz sędziego) 7-19 ławników, a więc tylko niektórzy spośród nich byli starszymi ziemskimi. Być może tzw. lawnicy starsi, wymienieni w 1532 r. w składzie lawy zatorskiego sądu ziemskiego, to właśnie starsi ziemscy. Pozostałych ławników zaczęto natomiast $\mathrm{z}$ biegiem czasu traktować jak deputowanych ziemskich w księstwach dolnośląskich ${ }^{31}$. W ten sposób sędzia ziemski wraz z lawnikami zaczęli pelnić funkcję stanowego wydziału ziemskiego, co było charakterystyczne dla ustroju terytoriów górnośląskich.

Niedostrzeżenie zachodzących zmian jest źródłem nieporozumień przy ocenie ustrojowej roli oświęcimskiego i zatorskiego sądu ziemskiego. Sądom tym przypisuje się bowiem rolę sejmiku ziemskiego ${ }^{32}$. Nieporozumienie bierze

\footnotetext{
${ }^{30}$ F. B ostel, Sqdownictwo ziemskie oświęcimskie i zatorskie od r. 1440-1565, Lwów 1889.

${ }^{31}$ M. J. Pta k, Zgromadzenia $i$ urzędy stanowe ksiesstwa glogowskiego od poczqtku XIV w. do 1742 r., Wroclaw 1991, s. 209 i n.

${ }^{32}$ Opinię taką wyraził F. B oste1, Sqdownictwo ziemskie..., s. 29: Otóż sqqdy te byly zarazem zjazdami szlachty, byly niejako sejmikami rycerstwa oświęcimskiego lub zatorskiego. Powtórzył ja S. K u tr ze ba, Prawa - przywileje - statuty i lauda księstw oświęcimskiego i zatorskiego, Kraków 1912, s. 228: Sqdy ziemskie lawnicze oświęcimski i zatorski uchwalaly niejednokrotnie lauda, które obowiqzywaly w obrębie każdego z tych księstw, zależnie od tego, który sqd je wydal. T e nże, Historja źródel dawnego prawa polskiego, t. II, Lwów 1926, s. 26: Dzialalność ustawadawczq króla uzupelnialy sq̨dy i starosta. Sqqdy ziemskie gajone, każdy zosobna, ustanawialy lauda, czyli uchwaly w sprawach sqdowych [...], ale także $i$ z zakresu prawa
} 
się stąd, że sąd ziemski odbywał sesje przy obowiązkowym udziale wszystkich ziemian, czyli rycerstwa księstwa. Był to zwyczaj występujący także w innych terytoriach górnośląskich, na przykład w księstwie cieszyńskim i karniowskim oraz w pszczyńskim wolnym państwie stanowym ${ }^{33}$. Miało to shużyć sprawniejszemu funkcjonowaniu sądu ziemskiego. Powszechna obecność ziemian sprzyjała szybkiemu rozstrzyganiu spraw sądowych, zapewniała kontrole działalności sądu i umożliwiała natychmiastową publikację wyroków wśród wszystkich podlegających jego jurysdykcji. Niejako ubocznym skutkiem tego zwyczaju była też zapewne powszechniejsza znajomość procedury sądowej i prawa sądowego. Posłużył on jednak również wygodzie ziemian, którzy przy tej okazji odbywali sejmiki ziemskie. Pragmatyzm tego rozwiązania polegał także na tym, że sesje sądu ziemskiego - przynajmniej od połowy XV w. - odbywały się $w$ kilku stałych i z góry określonych terminach. Świadczy to o braku skłonności do nazbyt częstego i nieregularnego uczestniczenia w zgromadzeniach publicznych. Odprawianie sejmików przy okazji sesji sądowych wcale nie oznacza, iż ziemianom górnośląskim - w tym oświęcimskim i zatorskim - obcy był organizacyjny rozdział funkcji jurysdykcyjnych i uchwałodawczych. Wręcz przeciwnie, ów rozdział był jedną $z$ fundamentalnych zasad ustrojowych. $Z$ tego powodu jeszcze $w$ latach trzydziestych XVIII w. sejmik cieszyński i sejmik pszczyński odbywały się w drugim dniu sesji sądu ziemskiego. Różnica między księstwem cieszyńskim a państwem pszczyńskim polegala na tym, że sesja cieszyńskiego sądu ziemskiego trwała sześć dni, a pszczyńskiego tylko trzy dni i przypadała w innych terminach niż sądu pszczyńskiego. W księstwie karniowskim praktyka odbywania sejmików w terminach sądu ziemskiego została jednak zniesiona ordynacją ziemską z $1673 \mathrm{r}$., ponieważ uznano, iż przynosi to szkodę sprawom prawnym rozpatrywanym w sądzie ziemskim.

Sąd ziemski księstwa oświęcimskiego odbywał się zwyczajnie cztery razy w roku, przeważnie we wtorek po: Trzech Królach (pierwsza połowa

publicznego [...]. Takie samo stanowisko prezentuje również A. Nowak owski, Dzieje ustroju..., s. 253: Prawdopodobnie na dlugo przed r. 1440 [...] sqd ziemski oświęcimski oprocz dzialalności sqdowniczej prowadzil także - podobnie jak to mialo miejsce w innych ksiestwach sląskich uzależnionych od Czech (cieszyńskim, opolskim, raciborskim) - dzialalność prawotwórczq, wydajqc uchwaly, zwane laudami. Lauda te uchwalane przez szlachte zebranq na rokach sqdowych mialy moc obowiqzujacq $w$ obrębie każdego z księstw, w zależności od sądu, który je wydal. Ibidem, s. 254: Mówiqu o prawotwórczej dzialalności sqadów ziemskich oświęcimsko-zatorskich, należy jeszcze dodać, że na sqsiednich terytoriach morawskich $w$ XIII-XIV stuleciu tamtejsza szlachta odbywala zjazdy ziemskie (coloquia generalia). Zjazdy te mialy równocześnie charakter sqdów ziemskich, gdzie podejmowano stosowne uchwaly, bęqce odpowiednikami laudów w księstwach oświęcimskim i zatorskim.

${ }^{33}$ M. J. Pta k, Zgromadzenia i urzędy stanowe ksiestwa cieszyńskiego, AUWr. 1992, nr 1193, Prawo CXCI, s. 31-60; Zgromadzenia i urzedy stanowe ksiestwa karniowskiego (1377-1743), AUWr. 1992, nr 1247, Prawo CXCIV, s. 47-82; Zgromadzenia i urzedy stanowe wolnego paristwa pszczyńskiego (1515-1742), AUWr. 1994, nr 1692, Prawo CCXL, s. 105-153. 
stycznia), tzw. przewodniej niedzieli (31 marca -4 maja), św. Janie Chrzcicielu (ostatnie dni czerwca) i św. Michale (koniec września i początek października). Natomiast sąd zatorski zbieral się na sesje zwyczajne też cztery razy w roku, ale w tzw. suche dni, czyli posty przypadające co kwartał (Quatuor tempora), przeważnie w czwartek po: Popielcu (15 lutego - 11 marca), św. Duchu (14 maja - 17 czerwca), podwyższeniu Krzyża Świętego (druga połowa września) i św. Lucji (połowa grudnia). Oznacza to, iż sejmik obu księstw zbierał się cztery razy w roku. Mogła się jednak zdarzyć mniejsza liczba sesji sejmikowych w roku ze względu na brak spraw mogących być przedmiotem deliberacji. Nie było też wykluczone odprawianie sejmików poza sesjami sądu ziemskiego. Przypuszczenia te potwierdzają obserwacje poczynione $\mathrm{w}$ innych terytoriach górnośląskich. Jednak wszystkie dotychczas znane uchwaly (lauda) zatorskie i oświęcimskie $\mathrm{z}$ lat 1460-1551 zapadly w terminach sesji sądu ziemskiego. Jedyny wyjątek stanowi uchwała sejmiku zatorskiego z 11 lutego 1524 r., poprzedzająca pierwszy termin sesji sądu ziemskiego. Formuły wstępne tych uchwał oraz ich tytuły jednoznacznie stwierdzają, iż zostały one powzięte przez ,panów ziemian", „panów ziemian i całe rycerstwo", „wszystką szlachte",, „panów i rycerstwo”, i tylko raz przez „lawę sądową i wszystkie rycerstwo” (17 września 1551 r.) oraz „panów i rycerstwo sławnej ławy sądowej" (6 października 1551 r.). Dwie ostatnie formuly sugerują kierowniczą rolę $w$ sejmiku lawy sądowej, a ściślej - zasiadających w niej urzędników jako wydziału ziemskiego. Ostatnia z nich dotyczy ponadto uchwały, która zapadła w odpowiedzi na skargę szlacheckiego pisarza ziemskiego, skierowaną przeciwko ,,panom ziemianom i obywatelom ziemi oświęcimskiej", a więc doszła do skutku w trybie procedury sądowej. Dowodzi to, iż za uchwałodawcę uchodził zasadniczo nie sąd ziemski, lecz szlachta zgromadzona na zjeździe $z$ okazji sesji tego sądu, co od czasu do czasu też podkreślano w nagłówku lub tekście uchwały. Nawet wówczas, gdy uchwała regulowała sprawy związane najściślej z funkcjonowaniem sądu ziemskiego. 